Fetal Diagnosis and Therapy

\title{
The Utility of the Congenital Pulmonary Airway Malformation-Volume Ratio in the Assessment of Fetal Echogenic Lung Lesions: A Systematic Review
}

\author{
Stefan C. Kane ${ }^{a-c}$ Emanuele Ancona ${ }^{a, b, d}$ Karen L. Reidy ${ }^{a, b}$ \\ Ricardo Palma-Dias ${ }^{\mathrm{a}-\mathrm{c}}$ \\ a Pregnancy Research Centre, Department of Maternal Fetal Medicine, The Royal Women's Hospital, Parkville, VIC, \\ Australia; 'bltrasound Services, Pauline Gandel Women's Imaging Centre, The Royal Women's Hospital, Parkville, \\ VIC, Australia; ' The University of Melbourne, Department of Obstetrics and Gynaecology, Parkville, VIC, Australia; \\ dObstetrics and Gynaecology Unit, Department of Women's and Children's Health, The University of Padua, Padua, Italy
}

\section{Keywords \\ Congenital pulmonary airway malformation • \\ Bronchopulmonary sequestration · Fetal echogenic lung lesion · Hydrops fetalis · Prenatal ultrasonography · Fetal diseases}

\begin{abstract}
Although relatively uncommon, the incidence of fetal echogenic lung lesions - a heterogeneous group of anomalies that includes congenital pulmonary airway malformations (CPAM) and bronchopulmonary sequestrations (BPS) - has increased recently. Two decades ago, the CPAM-volume ratio (CVR) was first described as a tool to predict the development of hydrops, with this outcome found to be unlikely in fetuses with CVRs of $\leq 1.6 \mathrm{~cm}^{2}$. Since then, no clear international consensus has evolved as to the optimal CVR thresholds for the prediction of fetal/neonatal outcomes. This systematic review aimed to assess all original research studies that reported on the predictive utility of the CVR. Potentially relevant papers were identified through searching for cita-
\end{abstract}

tions of the paper that originally described the CVR, in addition to keyword searches of electronic databases. Fifty-two original research papers were included in the final review. Of these, 34 used the CVR for descriptive purposes only, 5 assessed the validity of established thresholds in different populations, and 13 proposed new thresholds. The evidence identified in this review would suggest that a threshold much lower than $1.6 \mathrm{~cm}^{2}$ is likely to be of greater utility in most populations for many outcomes of perinatal relevance. For neonatal outcomes (mostly respiratory compromise at birth), a CVR on the initial ultrasound scan ranging from 0.5 to $1.0 \mathrm{~cm}^{2}$ appears to have the greatest predictive value. Although a number of studies concurred that $1.6 \mathrm{~cm}^{2}$ was a useful threshold for the prediction of hydrops, many others were unable to assess this due to the rarity of this complication. For this reason, thresholds as low as $0.4 \mathrm{~cm}^{2}$ may be more useful for the prediction of a broader range of fetal concerns, including mediastinal shift and fluid collections. Further large-scale studies are required to determine the true utility of this well-established index.

(c) 2019 S. Karger AG, Base

\section{KARGER}

(C) 2019 S. Karger AG, Basel

E-Mail karger@karger.com

www.karger.com/fdt
Dr. Stefan C. Kane

Department of Maternal Fetal Medicine, The Royal Women's Hospital

Corner Grattan Street and Flemington Road

Parkville, VIC 3052 (Australia)

E-Mail Stefan.Kane@thewomens.org.au 
Fig. 1. Image of the three orthogonal measurements of an ELL that permit calculation of the CPAM-volume ratio. Reproduced without modification from Hellmund et al. [44].
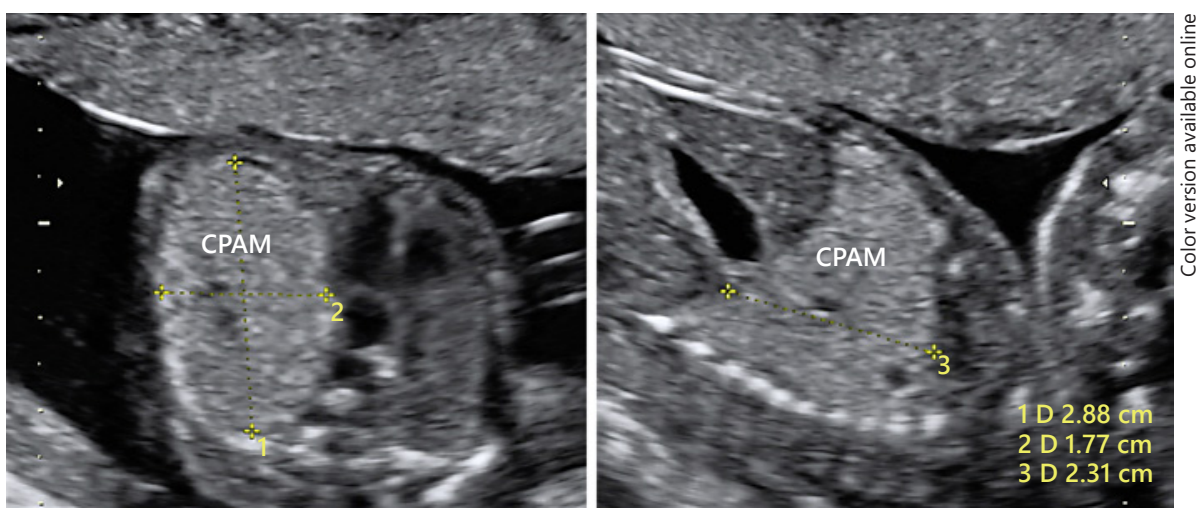

\section{Background/Objectives}

Fetal echogenic lung lesions (ELL) represent a heterogeneous group of congenital anomalies, including congenital pulmonary airways malformation (CPAM), bronchopulmonary sequestration (BPS), congenital lobar emphysema, bronchogenic cysts and bronchial atresia, with CPAM and BPS accounting for a majority of cases $[1,2]$. Although uncommon overall, advances in ultrasound technology have resulted in an apparent increase in their frequency [3], with CPAM now occurring at a rate of 0.94 per 10,000 live births [4]. There is considerable diversity in the literature regarding nomenclature and classification systems for fetal ELL [5-8], a situation made more complex by postnatal taxonomies that require a histopathological diagnosis $[9,10]$ even though many neonates born with such lesions do not have them excised $[11,12]$.

CPAM is a developmental malformation of the lower respiratory tract due to failure of maturation of bronchiolar structures during the pseudoglandular stage of lung development, resulting in overgrowth of the terminal bronchioles without corresponding alveoli. The lesion communicates with the tracheobronchial tree and derives its blood supply from the pulmonary arteries $[13,14]$. BPS result from the formation of a supernumerary nonfunctioning lung bud localised within the normal lung tissue (intralobar) or the development of separate pleura (extralobar). A systemic blood supply is present in both subtypes. Hybrid lesions displaying characteristics of CPAM and BPS have been described sonographically and histopathologically [13]. CHAOS is also commonly associated with echogenic fetal lungs, but is a discrete pathological entity that has a more predictably poor prognosis than other ELL [6]. Other lesions, such as bronchogenic cysts, are even less common.
These lesions may be associated with mass effect, pleural effusions, hydrops fetalis, fetal demise, or neonatal morbidity, and mortality secondary to respiratory embarrassment. It can be difficult to differentiate ELL antenatally, even when MRI is employed in addition to ultrasound $[15,16]$. The final histopathological diagnosis, when obtained, is often different to the presumptive antenatal categorisation [17-19]. What matters to parents is accurate information regarding the likely outcome of a pregnancy affected by ELL, rather than a precise pathological diagnosis. To this end, a range of sonographic predictors has been suggested, with the most commonly utilised being the CPAM-volume ratio (CVR): the ratio of the volume of the lung lesion (calculated as a prolate ellipse, i.e., height $\times$ length $\times$ width $\times 0.52$ ) to the head circumference, to normalise for gestation (Fig. 1). This ratio was first described by Liechty et al. [20] in abstract form in 1999. Its first mention in a peer-reviewed journal was by Crombleholme et al. [21] in 2002, in a series in which a CVR threshold of 1.6 $\mathrm{cm}^{2}$ was found to predict the later development of hydrops. Numerous subsequent studies have assessed the utility of this and other CVR thresholds in predicting a range of outcomes, both for lesions presumed to be CPAM, and those deemed to be BPS and of other origin [22].

This paper presents a systematic review of all publications of original research that has reported on the utility of the CVR in predicting the course and outcomes of fetal ELL, and seeks to summarise current evidence for the optimal clinical application of this sonographic index.

\section{Data Sources}

\section{Search Strategy and Selection Criteria}

This study was conducted according to the Preferred Reporting Items for Systematic Reviews and Meta-Anal- 
yses (PRISMA) [23]. A protocol was developed using the PRISMA-P Guidelines [24], and eligibility and exclusion criteria were agreed prior to study commencement. Studies were considered eligible if they reported fetal ultrasound diagnosis of ELL and assessment thereof using the CVR [21]. Despite its sonographic presentation as echogenic lungs, CHAOS cases were excluded from the analysis as they represent a different pathological entity with a more predictable prognosis.

Publications that did not describe antenatal assessment or postnatal outcomes, or those in which the diagnosis was only obtained after birth, were not eligible for inclusion. Additionally, only studies with a primary ultrasound diagnosis were included, whilst those relying exclusively on other technologies such as MRI were considered ineligible. To minimise the risk of publication bias, case series with fewer than 10 discrete cases were also excluded.

To identify papers of relevance, all of the publications that have cited the original paper by Crombleholme et al. [21] (2002) were reviewed, along with the reference lists of these publications. Additionally, a systematic literature search was undertaken using the PubMed, Medline, EmBase, Cochrane Collaboration, and Google Scholar databases, commencing from 2002 (when the CVR was first reported). The key search terms were: "congenital cystic adenomatoid malformation," "CCAM," "bronchopulmonary" AND "sequestration," "echogenic lung lesions," "congenital pulmonary airway malformation," "CPAM," "congenital lung lesion," and "fetal lung masses." Titles and abstracts from electronic searches were scrutinised independently by three reviewers (E.A., K.L.R., and S.C.K.) and assessed for eligibility, and full-text articles of all eligible studies were obtained. Disagreements were resolved by discussion between the three review authors; if consensus could not be reached, the opinion of a fourth author (R.P.-D.) was sought. Similarly, data extraction was performed by the two authors (E.A. and S.C.K.), and any discrepancies were addressed by a joint re-evaluation of the article with the other authors.

\section{Data Extraction}

The strict study inclusion criteria ensured that papers providing ambiguous or insufficient data regarding antenatal or postnatal management were excluded, as were those pertaining solely to postnatal diagnosis and management of congenital lung malformations.

The basic characteristics of each study were recorded, including study type, study period, number of patients, and inclusion and exclusion criteria. Each study was cat- egorised with respect to the way in which it utilised the CVR: (1) for descriptive purposes only; (2) to determine the utility of a previously proposed threshold in a specific population, and (3) to determine a new CVR threshold for specific fetal and neonatal outcomes.

For papers in categories 2 and 3, additional information was extracted and recorded, including the outcomes predicted by each CVR threshold, the timing of CVR measurement (at initial referral vs. serially), and, where relevant, the process used to determine the CVR threshold when one was proposed.

\section{Risk of Bias Assessment}

For each individual study, the risk of bias and study quality were assessed qualitatively, including representativeness of the sample, prospective collection of data according to a pre-established protocol, endpoints appropriate to the aim of the study, unbiased assessment of the study endpoint, follow-up period appropriate to the aim of the study, loss to follow-up less than $5 \%$, and inclusion of consecutive patients [25].

\section{Statistical Analysis}

Descriptive statistics were used to report on the outcome of specific studies where appropriate.

\section{Results}

The search strategy based on citations of the original study [21] and reference lists thereof yielded 346 potentially relevant papers. The search of electronic databases yielded 2,502 published works of potential relevance. Following assessment for eligibility and exclusion of duplicates, a total of 52 papers was included in the review [2, $16,21,22,26-73]$, representing 3,190 cases of ELL. The overall search process is summarised in Figure 2.

Of the 52 original papers reporting on the CVR, 34 [2, $16,26,28,29,31-34,36,37,39,43,45,47-62,65,68,70$, 73] did so in a descriptive capacity only: i.e., the ratio was used to describe the baseline characteristics of study populations, or to determine eligibility for inclusion in the study, or to evaluate the effect of interventions such as thoracoamniotic shunting and maternal steroid administration, without proposing or evaluating a threshold for the prediction of outcome.

Five papers $[22,30,41,67,71]$ reported solely on evaluations of existing thresholds. Four used the threshold of $1.6 \mathrm{~cm}^{2}$ for the development of hydrops as initially proposed by Crombleholme et al. [21] (2002), and 1 em- 


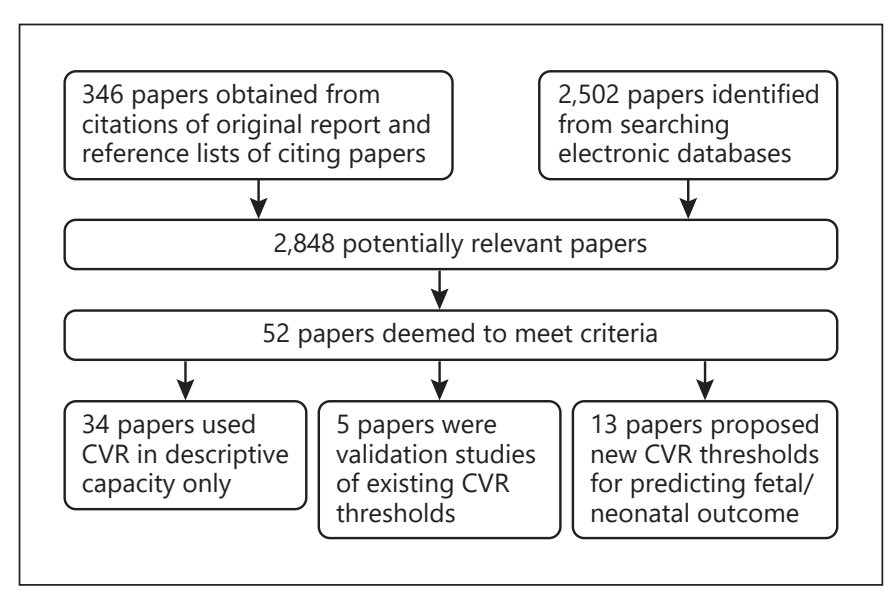

Fig. 2. Flowchart of the literature search process.

ployed the threshold of $2.0 \mathrm{~cm}^{2}$ for the need for neonatal surgery as proposed by Cass et al. [27] (2011). Four papers proposing new thresholds also evaluated the utility of the $1.6 \mathrm{~cm}^{2}$ threshold [27, 38, 66, 72]. All of these papers are summarised in Table 1.

Thirteen papers $[21,27,35,38,40,42,44,46,63,64$, $66,69,72$ ] proposed CVR thresholds for the prediction of a range of fetal and neonatal outcomes. Five papers, including the original study by Crombleholme et al. [21], assessed fetal outcomes, including hydrops, hydrothorax, heart failure, mediastinal shift, need for fetal intervention, and fetal demise. Seven studies addressed neonatal complications, largely respiratory compromise and the need for respiratory support after birth, but also including nursery admission, need for emergent surgery or ECMO, and death. Two studies presented a composite endpoint of fetal and neonatal outcomes that included, inter alia, perinatal death, hydrops, and the need for respiratory support after birth. These studies are all summarised in Table 2, including the population studied, the timing of CVR measurement, and the specific outcomes for which thresholds were proposed.

\section{Change in CVR over Time}

Six studies explicitly assessed the natural history of the change in CVR over time [35, 38, 40, 63, 67, 69]. In the largest series published to date - the French MALFPULM cohort study of 176 pregnancies affected by fetal lung lesions, first assessed at a mean of 25.8 weeks [35] - the CVR was noted to decrease in a constant fashion in cystic/mixed lesions, whereas in hyperechoic lesions, the CVR increased until 27 weeks and declined thereafter. Ehrenberg-Buchner et al. [38] (2013) found that the CVR of larger prenatal lung lesions increased to a peak at around 26 weeks, whereas that of smaller lesions stayed constant or decreased slightly, resulting in a peak mean CVR for the whole cohort of $0.89 \mathrm{~cm}^{2}$ at 26.3 weeks, declining to a final average of $0.58 \mathrm{~cm}^{2}$ at a mean of 30 weeks' gestation. Similarly, Tuzovic et al. [69] (2019) observed that the mean CVR decreased until 32 weeks and then stayed relatively constant in their cohort of 53 fetuses with congenital lung lesions. In contrast, the cohort of fetuses with congenital lung lesions studied by Feghali et al. [40] (2015) demonstrated an increase in the mean CVR until 32 weeks' gestation which then decreased if the infant was destined for regular nursery care. Infants who required neonatal intensive care had started with much larger CVRs (mean 1.92 vs. $0.31 \mathrm{~cm}^{2}$ ), which gradually decreased with advancing gestation.

In a study limited to BPS, Riley et al. [63] (2018) found that the gestational age associated with the highest mean CVR for all BPSs was $26 \pm 1$ weeks with subsequent decrease in mean CVR thereafter. Extralobar BPSs were less likely than intralobar BPSs to decrease in CVR or become isoechoic from initial to final evaluation (71 vs. $94 \%$ of lesions, respectively). Finally, Stoiber et al. [67] (2017) identified differential growth patterns between presumed CPAM and BPS in the same cohort. CPAM cases reached a higher mean volume at a mean of 6 weeks after diagnosis (30 weeks). After reaching the peak volume, the CPAM volume decreased in 11 of $24(46 \%)$, while $5(25 \%)$ remained stable and 5 (25\%) grew until delivery. BPS decreased or disappeared in 6 of $10(60 \%)$ cases and 2 remained stable, while 1 increased in size until delivery and the other did not have growth assessed.

\section{Risk of Bias Assessment}

The 18 papers that form the basis of this review were all of sufficient quality to permit inclusion. Their populations were well defined, and the observations performed thereupon were clearly protocolised and performed consistently. The outcomes and timeframes for assessment thereof were appropriate, and there was limited loss to follow-up given the short-term endpoints employed by most studies. All studies but one, however, were retrospective in nature, and the national referral status of the institutions in which some studies were performed would likely have resulted in a preponderance of more severe disease states in their cohorts. 
Table 1. Studies evaluating existing thresholds for the CPAM-volume ratio (CVR)

\begin{tabular}{|c|c|c|c|c|c|c|}
\hline Paper & Type of study & $\begin{array}{l}\text { Number and } \\
\text { type of cases }\end{array}$ & Outcome(s) & $\begin{array}{l}\text { CVR } \\
\text { threshold, } \\
\mathrm{cm}^{2}\end{array}$ & $\begin{array}{l}\text { Timing of CVR } \\
\text { measurement }\end{array}$ & Findings \\
\hline $\begin{array}{l}\text { Costanzo } \\
\text { et al. [30], } \\
2016\end{array}$ & $\begin{array}{l}\text { Retrospective } \\
\text { cohort }\end{array}$ & $\begin{array}{l}70 \text { fetuses with } \\
\text { pulmonary } \\
\text { malformations }\end{array}$ & $\begin{array}{l}\text { Fetal complica- } \\
\text { tions (severe medi- } \\
\text { astinal shift, hy- } \\
\text { drops or hydrotho- } \\
\text { rax), respiratory } \\
\text { distress at birth }\end{array}$ & 1.6 & $\begin{array}{l}\text { On initial } \\
\text { ultrasound scan } \\
\text { (median } 22 \text { weeks) }\end{array}$ & $\begin{array}{l}16 \text { out of } 70 \text { patients }(22.8 \%) \text { had CVR }>1.6 \\
\mathrm{~cm}^{2} ; 14 \text { out of these } 16 \text { cases developed fetal } \\
\text { complications }(87 \%) \text {. No fetus with CVR }<1.6 \\
\mathrm{~cm}^{2} \text { had fetal complications or respiratory } \\
\text { distress at birth }\end{array}$ \\
\hline $\begin{array}{l}\text { Fuchimoto } \\
\text { et al. [41], } \\
2018\end{array}$ & $\begin{array}{l}\text { Retrospective } \\
\text { cohort }\end{array}$ & $\begin{array}{l}36 \text { fetuses with } \\
\text { CPAMs who } \\
\text { subsequently } \\
\text { underwent } \\
\text { pulmonary } \\
\text { lobectomy }\end{array}$ & $\begin{array}{l}\text { Timing of pulmo- } \\
\text { nary lobectomy }\end{array}$ & 2.0 & $\begin{array}{l}\text { Maximum CVR } \\
\text { (mean gestational } \\
\text { age } 26.1 \text { weeks) }\end{array}$ & $\begin{array}{l}\text { Mean of the maximum CVR was } 2.18 \mathrm{~cm}^{2} \text {; all } \\
\text { patients having lobectomy within } 48 \mathrm{~h} \text { of birth } \\
\text { demonstrated a maximum CVR }>2.0 \mathrm{~cm}^{2} . \text { In } \\
\text { contrast, } 3 \text { of } 4 \text { patients requiring lobectomy } \\
\text { within } 30 \text { days of birth and } 14 \text { of } 15 \text { patients } \\
\text { undergoing elective lobectomy at } 8-10 \\
\text { months after birth had a maximum CVR } \\
<2.0 \mathrm{~cm}^{2}\end{array}$ \\
\hline $\begin{array}{l}\text { Stoiber et } \\
\text { al. [67], } \\
2017\end{array}$ & $\begin{array}{l}\text { Retrospective } \\
\text { cohort }\end{array}$ & $\begin{array}{l}37 \text { fetuses with } \\
\text { prenatally } \\
\text { diagnosed } \\
\text { CPAM or BPS }\end{array}$ & $\begin{array}{l}\text { Development of } \\
\text { hydrops }\end{array}$ & 1.6 & $\begin{array}{l}\text { Maximum CVR } \\
\text { (mean gestational } \\
\text { age } 30.1 \text { weeks for } \\
\text { CPAM, } 24.8 \text { weeks } \\
\text { for BPS) }\end{array}$ & $\begin{array}{l}\text { Mean maximum CVR for CPAM was } 1.35 \pm \\
1.5 \mathrm{~cm}^{2} \text {, and for BPS } 0.74 \pm 0.6 \mathrm{~cm}^{2} \text {; these } \\
\text { were not statistically significantly different. } \\
\text { Fetuses with CPAM and CVR } \leq 1.6 \mathrm{~cm}^{2} \text { devel- } \\
\text { oped hydrops in } 3 / 17(18 \%) \text { cases and with } \\
\text { CVR }>1.6 \mathrm{~cm}^{2} \text { in } 3 / 7(43 \%) \text {. Fetuses with BPS } \\
\text { did not develop hydrops when CVR was }>1.6 \\
\mathrm{~cm}^{2} \text {, but } 2(2 / 9,22 \%) \text { fetuses with BPS and } \\
\text { CVR } \leq 1.6 \mathrm{~cm}^{2} \text { progressed to hydrops }\end{array}$ \\
\hline $\begin{array}{l}\text { Xia et } \\
\text { al. [71], } \\
2017\end{array}$ & $\begin{array}{l}\text { Retrospective } \\
\text { cohort }\end{array}$ & $\begin{array}{l}115 \text { fetuses } \\
\text { with CPAM }\end{array}$ & Perinatal death & 1.6 & $\begin{array}{l}\text { Maximum CVR } \\
\text { (gestation not } \\
\text { provided) }\end{array}$ & $\begin{array}{l}\text { The median maximum CVR of the cohort was } \\
0.95 \mathrm{~cm}^{2} \text { (range, } 0.19-3.2 \text { ). There were } 4 \text { cases } \\
\text { with CVR }>1.6 \mathrm{~cm}^{2} \text {, the largest CVR up to } 3.2 \\
\mathrm{~cm}^{2} \text {, all of whom recovered well post-opera- } \\
\text { tion. Two infants died, } 1 \text { of them with CVR } \\
0.8 \mathrm{~cm}^{2} \text { with coexistent lobar emphysema, the } \\
\text { other with CVR } 1.5 \mathrm{~cm}^{2} \text {, both of whom had } \\
\text { been asymptomatic at birth; CVR was not a } \\
\text { statistically significant indicator of prognosis }\end{array}$ \\
\hline $\begin{array}{l}\text { Zhang et } \\
\text { al. [22], } \\
2014\end{array}$ & $\begin{array}{l}\text { Retrospective } \\
\text { cohort }\end{array}$ & $\begin{array}{l}68 \text { fetuses with } \\
\text { BPS }\end{array}$ & $\begin{array}{l}\text { Development of } \\
\text { hydrops, respira- } \\
\text { tory compromise } \\
\text { at birth }\end{array}$ & 1.6 & $\begin{array}{l}\text { On initial ultra- } \\
\text { sound scan (mean } \\
\text { gestational age } 24 \\
\text { weeks) }\end{array}$ & $\begin{array}{l}\text { All } 56 \text { cases }(82.4 \%, 56 / 68) \text { with CVR }<1.6 \\
\mathrm{~cm}^{2} \text { survived without prenatal hydrops or } \\
\text { postnatal respiratory symptoms. In the } 12 \\
\text { cases with CVR }>1.6 \mathrm{~cm}^{2}, 7(58.3 \%) \text { had hy- } \\
\text { drops, } 10(83.3 \%) \text { survived ( } 2 \text { elective ToPs) } \\
\text { and } 8(66.7 \%) \text { were symptomatic at birth. A } \\
\text { CVR of }>1.6 \mathrm{~cm}^{2} \text { was statistically significantly } \\
\text { more likely to be associated with hydrops or } \\
\text { respiratory compromise at birth }\end{array}$ \\
\hline $\begin{array}{l}\text { Cass et } \\
\text { al. [27], } \\
2011\end{array}$ & $\begin{array}{l}\text { Retrospective } \\
\text { cohort }\end{array}$ & $\begin{array}{l}82 \text { fetuses with } \\
\text { lung masses }\end{array}$ & $\begin{array}{l}\text { Development of } \\
\text { hydrops }\end{array}$ & 1.6 & $\begin{array}{l}\text { On initial ultra- } \\
\text { sound scan (mean } \\
\text { gestational age } 27.1 \\
\text { weeks) }\end{array}$ & $\begin{array}{l}\text { CVR }>1.6 \mathrm{~cm}^{2} \text { had a sensitivity, specificity, } \\
\mathrm{PPV} \text {, and NPV of } 0.91,0.84,0.48 \text {, and } 0.98 \text {, } \\
\text { respectively, for the development of hydrops }\end{array}$ \\
\hline $\begin{array}{l}\text { Ehrenberg- } \\
\text { Buchner et } \\
\text { al. [38], } \\
2013\end{array}$ & $\begin{array}{l}\text { Retrospective } \\
\text { cohort }\end{array}$ & $\begin{array}{l}64 \text { fetuses with } \\
\text { lung lesions }\end{array}$ & $\begin{array}{l}\text { Development of } \\
\text { hydrops }\end{array}$ & 1.6 & $\begin{array}{l}\text { On initial ultra- } \\
\text { sound scan (mean } \\
\text { gestational age } 24.3 \\
\text { weeks) }\end{array}$ & $\begin{array}{l}\text { Fetuses with CVR }>1.6 \mathrm{~cm}^{2} \text { were significantly } \\
\text { more likely to experience hydrops ( } 60 \mathrm{vs} \text {. } \\
1.8 \%) \text {, producing a sensitivity, specificity, } \\
\text { PPV, and NPV of } 0.75,0.97,0.6 \text {, and } 0.98 \text { for } \\
\text { this outcome, respectively }\end{array}$ \\
\hline $\begin{array}{l}\text { Shulman } \\
\text { et al. [66], } \\
2018\end{array}$ & $\begin{array}{l}\text { Retrospective } \\
\text { cohort }\end{array}$ & $\begin{array}{l}85 \text { fetuses with } \\
\text { CPAM }\end{array}$ & $\begin{array}{l}\text { Development of } \\
\text { hydrops, adverse } \\
\text { perinatal outcome } \\
\text { (fetal demise, } \\
\text { neonatal demise, } \\
\text { admission to } \\
\text { NICU) }\end{array}$ & 1.6 & $\begin{array}{l}\text { On initial ultra- } \\
\text { sound scan (me- } \\
\text { dian gestation } 21.3 \\
\text { weeks) }\end{array}$ & $\begin{array}{l}33.3 \% \text { of fetuses with an adverse perinatal } \\
\text { outcome had a CVR }<1.6 \mathrm{~cm}^{2} \text {, whereas } 84.9 \% \\
\text { of fetuses without such an outcome had a } \\
\text { CVR in this range; } 12.5 \% \text { of fetuses who de- } \\
\text { veloped hydrops had a CVR }<1.6 \mathrm{~cm}^{2} \text {, where- } \\
\text { as } 80.3 \% \text { of fetuses without such an outcome } \\
\text { had a CVR in this range }\end{array}$ \\
\hline
\end{tabular}


Table 1 (continued)

\begin{tabular}{lllllll}
\hline Paper & Type of study & $\begin{array}{l}\text { Number and } \\
\text { type of cases }\end{array}$ & Outcome(s) & $\begin{array}{l}\text { CVR } \\
\text { threshold, } \\
\mathrm{cm}^{2}\end{array}$ & $\begin{array}{l}\text { Timing of CVR } \\
\text { measurement }\end{array}$ & Findings \\
\hline $\begin{array}{l}\text { Yong et } \\
\text { al. [72], 2012 }\end{array}$ & $\begin{array}{l}\text { Retrospective } \\
\text { cohort }\end{array}$ & $\begin{array}{l}71 \text { fetuses with } \\
\text { CPAM }\end{array}$ & $\begin{array}{l}\text { Coexistent } \\
\text { hydrops }\end{array}$ & 1.6 & $\begin{array}{l}\text { On initial ultra- } \\
\text { sound scan (me- } \\
\text { dian gestational } \\
\text { age 21 weeks) }\end{array}$ & $\begin{array}{l}\text { All hydropic fetuses in this series were so } \\
\text { afflicted at the time of initial review, and none } \\
\text { developed it later. A CVR }>1.6 \mathrm{~cm}^{2} \text { was signif- } \\
\text { icantly associated with coexistent hydrops } \\
\text { (OR 19.00, 95\% CI 2.86-126.33) }\end{array}$ \\
\hline
\end{tabular}

NICU, neonatal intensive care unit; PPV, positive predictive value; NPV, negative predictive value; ToP, termination of pregnancy.

\section{Discussion/Conclusion}

In many centres, calculation of the CVR has become an integral aspect of the sonographic assessment of an echogenic fetal lung lesion, with guidelines now commonly suggesting its use [19]. Although the original study in which this index was proposed was elegant in design and execution [21], it is striking to observe the heterogeneous outcomes of studies undertaken since then, to the extent that a clearly defined threshold above which a poor outcome can reasonably be expected, or conversely below which a favourable outcome might be anticipated, cannot easily be defined.

There are many reasons as to why this might be the case. The studies themselves clearly demonstrate substantial heterogeneity, with populations that differ in institution(s) of origin, lesion studied and timing of CVR assessment, and with varied approaches to the calculation of predictive thresholds (absolute vs. AUC-derived), thereby precluding meta-analysis of their findings. Furthermore, ultrasound technology has advanced substantially in the time since Crombleholme's original paper [21], with considerable improvements in image resolution. Additionally, more pregnant women are having more scans, increasing the opportunity for the identification of lesions that previously would have gone unrecognised [3]. It is thus likely that we are now identifying a greater proportion of lesions of lower perinatal significance, highlighted by the relative infrequency of hydrops and generally favourable outcomes in more recent studies conducted in cohorts derived from broader populations $[35,38,46,72]$ than those found at national referral centres for fetal intervention $[21,26,60]$.

For this reason, leaving aside its heterogeneity, the evidence presented in this review might suggest that a threshold much lower than $1.6 \mathrm{~cm}^{2}$ is likely to be of greater utility in most populations for many outcomes of perinatal relevance. For neonatal outcomes such as respira- tory symptoms, need for surgery, nursery admission, ECMO, or death, a CVR on the initial ultrasound scan ranging from $0.5 \mathrm{~cm}^{2}$ [69] to $1.0 \mathrm{~cm}^{2}$ [38] appears to have the greatest predictive value (i.e., thresholds above which these outcomes are more likely to occur in neonates), with most studies $[40,42,72]$ tending toward the lower rather than upper end of this spectrum. Similarly, the two studies that evaluated composite fetal/neonatal outcomes (including perinatal death, hydrops, and the need for postnatal respiratory support) found thresholds of 0.91 and $0.45 \mathrm{~cm}^{2}$ to have the highest negative predictive values (i.e., thresholds below which these composite outcomes did not occur) when derived from the initial ultrasound scan $[44,46]$. However, given that these alternative thresholds are largely based on relatively small retrospective studies, caution needs to be exercised in their application, as their true clinical meaning is yet to be tested in prospective studies of adequate size.

It is not surprising that CVR thresholds for the outcome of hydrops are relatively high, ranging up to $2.2 \mathrm{~cm}^{2}$ [66], but even here one study found a lower threshold of $0.75 \mathrm{~cm}^{2}$ [63] on the maximum rather than initial CVR assessment, although admittedly this was in a cohort limited to BPS. The fetal outcome of 'compression' used by the MALFPULM investigators - technically a composite of mediastinal shift, eversion of the diaphragm, hydrothorax, ascites, polyhydramnios or hydrops - may be more clinically useful than hydrops alone, and was unlikely with a CVR $<0.4 \mathrm{~cm}^{2}$ on initial assessment in this large contemporary cohort [35].

The patterns of lesion growth as assessed by serial CVR measurement also varied among studies, although generally lesions were seen to grow until the late second or early third trimester, and then plateau or decrease slightly in size. The highest specificities of any CVR assessment in any study were those of the final assessments in the cohort of Ehrenberg-Buchner et al. [38] (2013), in keeping with the intuitive concept that the largest lesions at the end of 
Table 2. Studies proposing thresholds for the CPAM-volume ratio (CVR) for the prediction of adverse fetal and neonatal outcome

\begin{tabular}{|c|c|c|c|c|c|c|c|c|}
\hline \multirow[t]{2}{*}{ Paper } & \multirow[t]{2}{*}{ Study type } & \multirow{2}{*}{$\begin{array}{l}\text { Number and type } \\
\text { of cases }\end{array}$} & \multirow{2}{*}{$\begin{array}{l}\text { Timing of } \\
\text { CVR measurement }\end{array}$} & \multicolumn{5}{|l|}{ Other findings } \\
\hline & & & & outcome(s) & $\begin{array}{l}\text { CVR threshold sensitivity, } \\
\mathrm{cm}^{2}\end{array}$ & specificity & PPV & NPV \\
\hline
\end{tabular}

Fetal outcomes Crombleholme

$\begin{array}{ll}\text { Crombleholme } & \text { Retrospective and } \\ \text { et al. [21],2002 } & \text { prospective cohor }\end{array}$ prospective cohort

32 cases of On initial ultrasound CPAM in retrospective scan (gestation not development cohort; 58 in provided the prospective validation cohort

Cass et al.

[27], 2011

Retrospective cohort

82 fetuses with lung

masses

On initial ultrasound $\quad$ Hydrops
scan (mean gestation
$27.1 \pm 5.1$ weeks)

$27.1 \pm 5.1$ weeks)
Hydrops

$>1.6 \quad$ N/A

N/A

N/A N/A

CVR of $1.7 \mathrm{~cm}^{2}$ was the mean $+2 \mathrm{SD}$ in non-hydropic fetuses in the development cohort. In the validation cohort, excluding fetuses with a dominant cyst, $2.8 \%$ with CVR $\leq 1.6 \mathrm{~cm}^{2}$ at presentation developed hydrops, and $75 \%$ of those with CVR $>1.6 \mathrm{~cm}^{2}$

$\begin{array}{llllll}\text { Hydrops } & >0.75 & 1.0 & 0.45 & 0.23 & 1.0 \\ & >1.4 & 1.0 & 0.76 & 0.41 & 1.0 \\ & >1.6 & 0.91 & 0.84 & 0.48 & 0.98 \\ & >2.0 & 0.91 & 0.88 & 0.56 & 0.98 \\ & >2.2 & 0.82 & 0.9 & 0.56 & 0.97 \\ \text { Heart failure } & >2.0 & 0.88 & 0.86 & \text { N/A } & \text { N/A } \\ \text { Tetal intervention } & >2.0 & 0.83 & 0.88 & \text { N/A } & \text { N/A } \\ \text { Mortality } & >2.0 & 0.86 & 0.83 & \text { N/A } & \text { N/A } \\ \text { eetal intervention or mortality } & >2.0 & 0.82 & 0.93 & \text { N/A } & \text { N/A }\end{array}$

CVR correlated strongly with the development of hydrops and the need for fetal therapy with an AUC o $0.96(p<0.0001)$ and $0.88(p<0.0001)$, respectively

\begin{tabular}{|c|c|c|c|c|c|c|c|}
\hline $\begin{array}{l}\text { Delacourt et al. } \\
{[35], 2019}\end{array}$ & Prospective cohort & $\begin{array}{l}176 \text { fetuses with } \\
\text { congenital pulmonary } \\
\text { malformations }\end{array}$ & $\begin{array}{l}\text { On initial ultrasound } \\
\text { scan (mean gestation } \\
25.8 \pm 0.3 \text { weeks) }\end{array}$ & $\begin{array}{l}\text { "Compression" (mediastinal shift, ever- }>0.4 \\
\text { sion of the diaphragm, hydrothorax, } \\
\text { ascites, polyhydramnios or hydrops) } \\
\text { For fetuses with no sign of compression at dia } \\
\text { higher (aOR 7.0; 95\% CI 1.6-29.9) when CVR }\end{array}$ & $\mathrm{N} / \mathrm{A}$ & $\mathrm{N} / \mathrm{A}$ & N/A \\
\hline
\end{tabular}

\begin{tabular}{|c|c|c|c|c|c|c|c|c|}
\hline \multirow{2}{*}{$\begin{array}{l}\text { Riley et al. } \\
{[63], 2018}\end{array}$} & \multirow[t]{2}{*}{ Retrospective cohort } & \multirow[t]{2}{*}{103 fetuses with BPS } & \multirow{2}{*}{$\begin{array}{l}\text { Maximum CVR } \\
\text { (mean gestational } \\
\text { age } 26 \pm 1 \text { weeks) }\end{array}$} & Hydrops \pm hydrothorax & $<0.75$ & N/A & N/A & N/A $\quad 0.98$ \\
\hline & & & & \multicolumn{5}{|c|}{$\begin{array}{l}\text { CVR }>0.75 \mathrm{~cm}^{2} \text { increased the odds of hydrothorax } \pm \text { hydrops by a ratio of } 28.7 \text { ( } 95 \% \text { CI } 3.1-268, p= \\
0.003 \text { ). }\end{array}$} \\
\hline
\end{tabular}

\begin{tabular}{lllll}
\hline $\begin{array}{l}\text { Shulman et al. [66], } \\
2018\end{array}$ & Retrospective cohort & 85 fetuses with CPAM & $\begin{array}{l}\text { On initial ultrasound } \\
\text { scan (median gestational } \\
\text { age 21.3 weeks) }\end{array}$ & $\begin{array}{l}\text { Hydrops } \\
\text { Each one unit increase in CVR was associated with an aOR of 4.6 (95\% CI 2.0-10.3, } p<0.001) \text { for } \\
\text { adverse perinatal outcome, and } 8.3(95 \% \text { CI 1.7-40.1, } p=0.009) \text { for development of hydrops }\end{array}$
\end{tabular}

Neonatal outcomes

Ehrenberg-Buchner Retrospective cohort 64 fetuses with lung lesions
Respiratory symptoms

Initial ultrasound scan

Final CVR

Initial ultrasound scan Perinatal resection

Maximum CVR

Final CVR

(gestations not provided)

$\begin{array}{lllll}>1.0 & 0.63 & 0.86 & 0.42 & 0.94 \\ & 0.9 & 0.93 & 0.75 & 0.98 \\ & 0.75 & 0.98 & 0.75 & 0.98 \\ & 0.83 & 0.88 & 0.45 & 0.98 \\ & 1.0 & 0.94 & 0.75 & 1.0 \\ & 1.0 & 0.98 & 0.75 & 1.0\end{array}$
and the need for lung resection at birth $(p<0.01)$.

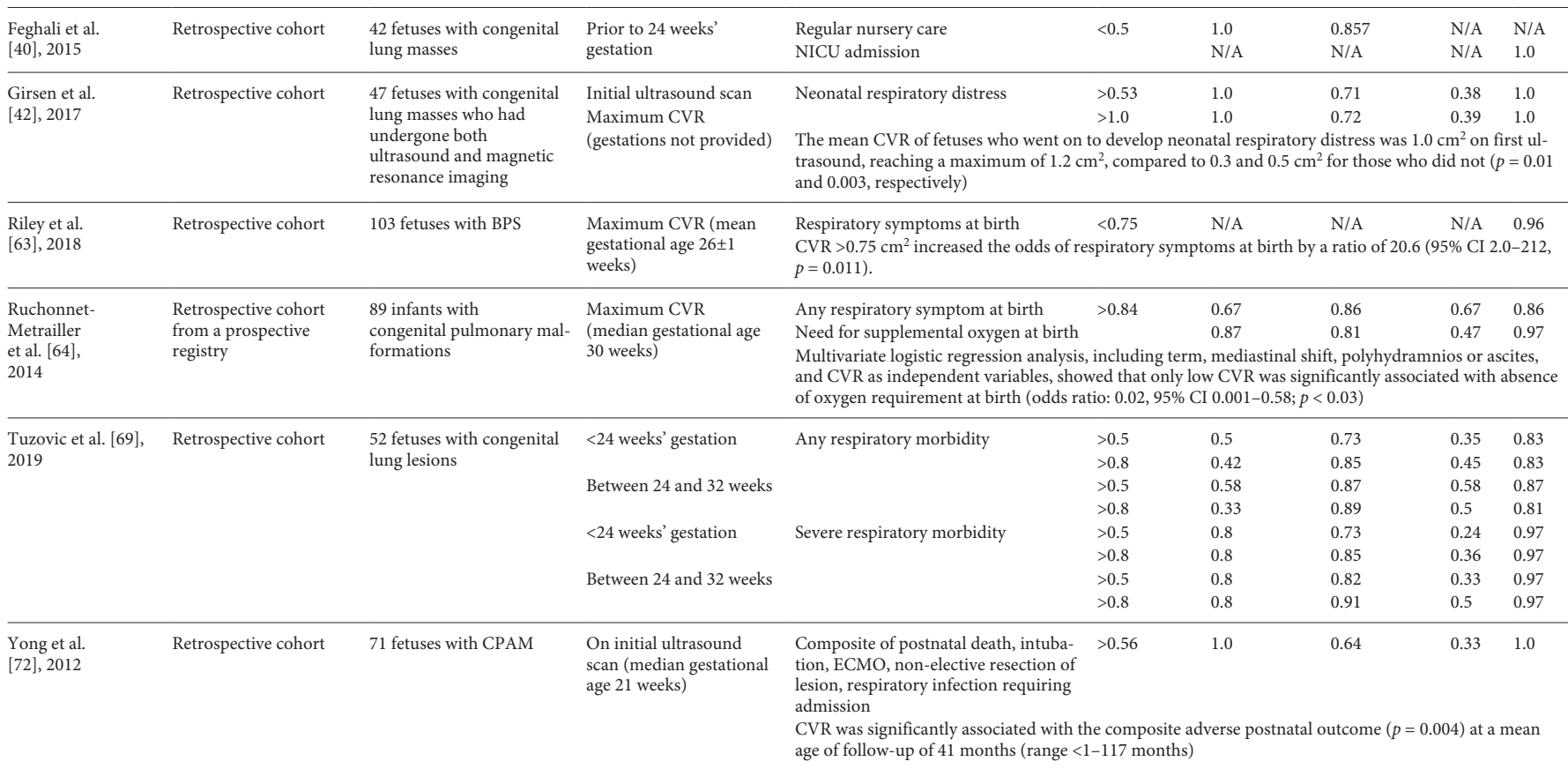


Table 2 (continued)

\begin{tabular}{|c|c|c|c|c|c|c|c|c|c|}
\hline \multirow[t]{2}{*}{ Paper } & \multirow[t]{2}{*}{ Study type } & \multirow{2}{*}{$\begin{array}{l}\text { Number and type } \\
\text { of cases }\end{array}$} & \multirow{2}{*}{$\begin{array}{l}\text { Timing of } \\
\text { CVR measurement }\end{array}$} & \multicolumn{6}{|l|}{ Other findings } \\
\hline & & & & outcome(s) & $\begin{array}{l}\mathrm{CVR} \text { th } \\
\mathrm{cm}^{2}\end{array}$ & ld sensitivity, & specificity & PPV & NPV \\
\hline \multicolumn{10}{|c|}{ Composite fetal/neonatal outcomes } \\
\hline $\begin{array}{l}\text { Hellmund } \\
\text { et al. [44], } \\
2016\end{array}$ & Retrospective cohort & 67 fetuses with CPAM & $\begin{array}{l}\text { On initial ultrasound scan } \\
\text { (median gestational age } 22 \\
\text { weeks) }\end{array}$ & $\begin{array}{l}\text { Perinatal death, termination of } \\
\text { pregnancy, hydrops, need for prenatal } \\
\text { intervention such as pleural drainage } \\
\text { and/or thoracocentesis or need for } \\
\text { postnatal respiratory assistance }\end{array}$ & $\begin{array}{l}<0.91 \\
>1.68\end{array}$ & $\begin{array}{l}0.89 \\
0.58\end{array}$ & $\begin{array}{l}0.71 \\
0.97\end{array}$ & $\begin{array}{l}0.62 \\
0.91\end{array}$ & $\begin{array}{l}0.93 \\
0.81\end{array}$ \\
\hline \multirow{2}{*}{$\begin{array}{l}\text { Kane et al. } \\
{[46], 2017}\end{array}$} & \multirow[t]{2}{*}{ Retrospective cohort } & \multirow{2}{*}{$\begin{array}{l}65 \text { fetuses with echogenic } \\
\text { lung lesions }\end{array}$} & \multirow{2}{*}{$\begin{array}{l}\text { On initial ultrasound scan } \\
\text { (mean gestational age } \\
22+6 \text { weeks) }\end{array}$} & \multirow{2}{*}{$\begin{array}{l}\text { Fetal/neonatal demise, hydrops, } \\
\text { requirement for neonatal intubation/ } \\
\text { ventilation, or surgery in the first } \\
\text { year of life }\end{array}$} & $<0.45$ & 1.0 & N/A & $\mathrm{N} / \mathrm{A}$ & 1.0 \\
\hline & & & & & \multicolumn{5}{|c|}{$\begin{array}{l}\text { The CVR below which no fetus/neonate experienced an adverse } \\
\text { outcome up to the age of } 1 \text { year was } 0.15 \mathrm{~cm}^{2}\end{array}$} \\
\hline
\end{tabular}

PPV, positive predictive value; NPV, negative predictive value; CPAM, congenital pulmonary airway malformation; BPS, bronchopulmonary sequestration; SD, standard deviation; CI, confidence interval; AUC, area under the receiver operating characteristic curve; aOR, adjusted odds ratio; ECMO, extracorporeal membrane oxygenation.

the pregnancy, either on account of persistent growth or failure to diminish in size, are most likely to result in an adverse outcome.

Many of the studies identified in this review sought to compare the capacity of the sonographically derived CVR to predict various fetal and neonatal outcomes with other indices and variables, such as MRI-derived CVR [39], cardiomediastinal shift angle [66], cardiac axis and cardiac position [69], and absolute measures of lesion volume by ultrasound [42] and MRI [16, 73]. None has conclusively demonstrated sufficient superiority to the CVR to merit its replacement as a key component of the sonographic assessment of fetal ELL.

The disparate findings of studies included in this review invite the question of how a more precise estimate of the CVR's predictive utility might be achieved. Notwithstanding their other variations, studies included in this review were consistent without exception in the method employed for assessment of the CVR. As a result, an individual patient data meta-analysis (IPD-MA) could be one means by which potentially greater value might be extracted from extant data. However, a significant limitation of the individual studies, and thus any meta-analysis thereof, is that the vast majority are retrospective in nature, increasing the chance of case selection bias [74]. For this reason, further prospective studies - ideally at a national level, like the MALFPULM cohort [35], - would be very valuable. The requisite infrastructure for these register-type projects should, of course, be deployed for other fetal anomalies as well, enhancing their value and helping to justify the cost of their establishment. Such studies should use consistent nomenclature, assess the CVR at pre-specified gestations, use internationally agreed definitions for diagnoses such as hydrops, and ensure that any and all "core outcome" sets of relevance to these populations are employed (such as those developed by the Core Outcomes in Women's and Newborn Health [CROWN] initiative [75]).

In the meantime, it would not be inappropriate for clinical practice guidelines - and the institutions to which they apply - to adopt a more nuanced approach to the use of the CVR for echogenic fetal lung lesions, rather than the longstanding $1.6 \mathrm{~cm}^{2}$ threshold generally employed to inform patient counselling and determine frequency of surveillance. Although this review has shown that this original threshold is not inappropriate for the prediction of hydrops, lower thresholds - once adequately assessed in prospective studies - may be of greater utility for the exclusion of other fetal and neonatal concerns that are more frequent in incidence, and thus potentially of greater relevance to fetal medicine practitioners and their patients alike.

\section{Acknowledgements}

The authors would like to acknowledge the staff of the Health Sciences Library at the Royal Melbourne Hospital for their assistance in sourcing the full text of a number of the papers cited in this review. Figure 1 has been reproduced without modification from Hellmund et al. [44] (2016) under the auspices of the Creative Commons Attribution Licence (CC BY 4.0 International).

\section{Statement of Ethics}

The authors have no ethical conflicts to disclose.

\section{Disclosure Statement}

The authors have no conflicts of interest to declare. 


\section{Funding Sources}

S.C.K. is supported by an Australian Government Research Training Program Scholarship, and by a Postgraduate Scholarship from the Australian National Health and Medical Research Council. His $\mathrm{PhD}$ project is supported by grants from the Research Foundation of the Royal Australian and New Zealand College of Obstetricians and Gynaecologists, and from the Australasian Society for Ultrasound in Medicine. No funding body had direct involvement in the preparation or approval of the manuscript.

\section{Author Contributions}

All authors made substantial contributions to the conception and design of the work, and the analysis and interpretation of data contained therein. The literature searches were performed by E.A., K.L.R., and S.C.K. The manuscript was drafted by E.A. and S.C.K., and all authors revised it critically for important intellectual content. All authors have given final approval of the version to be published, and all agree to be accountable for all aspects of the work in ensuring that questions related to the accuracy or integrity of any part of the work are appropriately investigated and resolved.

\section{References}

1 Cavoretto P, Molina F, Poggi S, Davenport M, Nicolaides KH. Prenatal diagnosis and outcome of echogenic fetal lung lesions. Ultrasound Obstet Gynecol. 2008 Nov;32(6):76983.

2 Macardle CA, Ehrenberg-Buchner S, Smith EA, Dillman JR, Mychaliska GB, Treadwell MC, et al. Surveillance of fetal lung lesions using the congenital pulmonary airway malformation volume ratio: natural history and outcomes. Prenat Diagn. 2016 Mar;36(3): 282-9.

3 Burge D, Wheeler R: Increasing incidence of detection of congenital lung lesions. Pediatr Pulmonol 2010;45:103;104 author reply. https://doi.org/10.1002/ppul.21150.

4 Kotecha S, Barbato A, Bush A, Claus F, Davenport M, Delacourt C, et al. Antenatal and postnatal management of congenital cystic adenomatoid malformation. Paediatr Respir Rev. 2012 Sep;13(3):162-70; quiz 170-1.

5 Puligandla PS, Laberge JM. Congenital lung lesions. Clin Perinatol. 2012 Jun;39(2):33147.

6 Benachi A: Echogenic fetal lung lesions. Ultrasound Obstet Gynecol. 2008 Nov;32:(6): 729-31. https://doi.org/10.1002/uog.6242.

7 Achiron R, Zalel Y, Lipitz S, Hegesh J, Mazkereth R, Kuint J, et al. Fetal lung dysplasia: clinical outcome based on a new classification system. Ultrasound Obstet Gynecol. 2004 Aug;24(2):127-33.

8 Sebire NJ. Fetal lung lesions: a new classification of fetal lung dysplasia. Ultrasound Obstet Gynecol. 2004 Oct;24(5):590-1.

9 Stocker JT. Symposium 24: non-neoplastic lung disease. Histopathology. 2002;41 S2: $424-58$.

10 Stocker JT, Dehner LP. Pediatric pathology. 3rd ed. Philadelphia: Lippincott Williams \& Wilkins; 2001.

11 Stanton M, Njere I, Ade-Ajayi N, Patel S, Davenport M. Systematic review and meta-analysis of the postnatal management of congenital cystic lung lesions. J Pediatr Surg. 2009 May; 44(5):1027-33.

$12 \mathrm{Ng} \mathrm{C}$, Stanwell J, Burge DM, Stanton MP Conservative management of antenatally diagnosed cystic lung malformations. Arch Dis Child. 2014 May;99(5):432-7.
13 Fowler DJ, Gould SJ. The pathology of congenital lung lesions. Semin Pediatr Surg. 2015 Aug;24(4):176-82.

14 Gajewska-Knapik K, Impey L. Congenital lung lesions: prenatal diagnosis and intervention. Semin Pediatr Surg. 2015 Aug;24(4):156-9.

15 Alamo L, Reinberg O, Vial Y, Gudinchet F, Meuli R. Comparison of foetal US and MRI in the characterisation of congenital lung anomalies. Eur J Radiol. 2013 Dec;82(12):e860-6.

16 Beydon N, Larroquet M, Coulomb A, Jouannic JM, Ducou le Pointe $\mathrm{H}$, Clément $\mathrm{A}$, et al. Comparison between US and MRI in the prenatal assessment of lung malformations. Pediatr Radiol. 2013 Jun;43(6):685-96.

17 Kuratsuji G, Hokuto I, Higuchi M, Koinuma G, Morikawa Y, Hoshino K, et al. Final diagnosis in patients with congenital cystic lung disease detected by fetal ultrasonography. $\mathrm{Pe}$ diatr Int. $2011 \mathrm{Feb} ; 53(1): 131-2$.

18 Adzick NS. Management of fetal lung lesions. Clin Perinatol. 2009 Jun;36(2):363-76.

19 David M, Lamas-Pinheiro R, Henriques-Coelho T. Prenatal and Postnatal Management of Congenital Pulmonary Airway Malformation. Neonatology. 2016;110(2):101-15.

20 Liechty KW, Coleman BG, Howell LJ, Flake AW, Adzick NS. Elevated cystic adenomatoid malformation volume ratio (CVR) is associated with development of hydrops. Am J Obstet Gynecol. 1999;180:S165.

21 Crombleholme TM, Coleman B, Hedrick H, Liechty K, Howell L, Flake AW, et al. Cystic adenomatoid malformation volume ratio predicts outcome in prenatally diagnosed cystic adenomatoid malformation of the lung. J Pediatr Surg. 2002 Mar;37(3):331-8.

22 Zhang H, Tian J, Chen Z, Ma X, Yu G, Zhang J, et al. Retrospective study of prenatal diagnosed pulmonary sequestration. Pediatr Surg Int. 2014 Jan;30(1):47-53.

23 Moher D, Liberati A, Tetzlaff J, Altman DG: Preferred reporting items for systematic reviews and meta-analyses: the PRISMA statement. 2009.

24 Shamseer L, Moher D, Clarke M, Ghersi D, Liberati A, Petticrew M, et al.; PRISMA-P Group. Preferred reporting items for systematic review and meta-analysis protocols (PRISMA-P) 2015: elaboration and explanation. BMJ. 2015 Jan;350:g7647.
25 Slim K, Nini E, Forestier D, Kwiatkowski F, Panis Y, Chipponi J. Methodological index for non-randomized studies (minors): development and validation of a new instrument. ANZ J Surg. 2003 Sep;73(9):712-6.

26 Cass DL, Olutoye OO, Ayres NA, Moise KJ Jr, Altman CA, Johnson A, et al. Defining hydrops and indications for open fetal surgery for fetuses with lung masses and vascular tumors. J Pediatr Surg. 2012 Jan;47(1):40-5.

27 Cass DL, Olutoye OO, Cassady CI, Moise KJ, Johnson A, Papanna R, et al. Prenatal diagnosis and outcome of fetal lung masses. J Pediatr Surg. 2011 Feb;46(2):292-8.

28 Cass DL, Olutoye OO, Cassady CI, Zamora IJ, Ivey RT, Ayres NA, et al. EXIT-to-resection for fetuses with large lung masses and persistent mediastinal compression near birth. J Pediatr Surg. 2013 Jan;48(1):138-44.

29 Chung VW, To WW. Antenatal diagnosis of congenital fetal lung lesions and postnatal outcome - a case series and review of the literature. Hong Kong J Gynaecol Obstet Midwifery. 2014;14:16-23.

30 Costanzo S, Filisetti C, Vella C, Rustico M, Fontana P, Lista G, et al. Pulmonary Malformations: Predictors of Neonatal Respiratory Distress and Early Surgery. J Neonatal Surg. 2016 Jul;5(3):27.

31 Cruz-Martínez R, Nieto-Castro B, MartínezRodríguez M, Gámez-Varela A, Ahumada-Angulo E, Luna-García J, et al. Thoracic Changes after Full Laser Ablation of the Feeding Artery in Fetuses with Bronchopulmonary Sequestration. Fetal Diagn Ther. 2018;44(3):166-72.

32 Curran PF, Jelin EB, Rand L, Hirose S, Feldstein VA, Goldstein RB, et al. Prenatal steroids for microcystic congenital cystic adenomatoid malformations. J Pediatr Surg. 2010 Jan;45(1):145-50.

33 Danzer E, Hoffman C, D’Agostino JA, Boelig MM, Gerdes M, Bernbaum JC, et al. Short-Term Neurodevelopmental Outcome in Children Born With High-Risk Congenital Lung Lesions. Ann Thorac Surg. 2018 Jun;105(6):1827-34.

34 Danzer E, Siegle J, D’Agostino JA, Gerdes M, Hoffman C, Bernbaum J, et al. Early neurodevelopmental outcome of infants with highrisk fetal lung lesions. Fetal Diagn Ther. 2012; $31(4): 210-5$. 
35 Delacourt C, Bertille N, Salomon LJ, Benachi A, Henry E, Massardier J, Mottet N, Rosenblatt J, Sartor A, Thong-Vanh C, Valat-Rigot AS, Winer N, Lelong N, Khoshnood B; Prenatal MALFPULM Study Group. Natural prenatal history of congenital pulmonary malformations: the MALFPULM population-based cohort study. Ultrasound Obstet Gynecol. 2019 Sep;54(3):381-88.

36 Derderian SC, Coleman AM, Jeanty C, Lim FY, Shaaban AM, Farrell JA, et al. Favorable outcomes in high-risk congenital pulmonary airway malformations treated with multiple courses of maternal betamethasone. J Pediatr Surg. 2015 Apr;50(4):515-8.

37 Derderian SC, Jayme CM, Cheng LS, Keller RL, Moon-Grady AJ, MacKenzie TC. Mass Effect Alone May Not Explain Pulmonary Vascular Pathology in Severe Congenital Diaphragmatic Hernia. Fetal Diagn Ther. 2016; 39(2):117-24.

38 Ehrenberg-Buchner S, Stapf AM, Berman DR, Drongowski RA, Mychaliska GB, Treadwell MC, Kunisaki SM: Fetal lung lesions: can we start to breathe easier? Am J Obstet Gynecol. 2013 Feb;208(2):151.e1-7.

39 Euser AG, Meyers ML, Zaretsky MV, Crombleholme TM: Comparison of congenital pulmonary airway malformation volume ratios calculated by ultrasound and magnetic resonance imaging. J Matern Fetal Neonatal Med. 2016 Oct;29(19):3172-7.

40 Feghali M, Jean KM, Emery SP. Ultrasound assessment of congenital fetal lung masses and neonatal respiratory outcomes. Prenat Diagn. 2015 Dec;35(12):1208-12.

41 Fuchimoto Y, Watanabe T, Fujino A, Kanamori Y, Itoh Y, Wada S, et al. Predictors of early lobectomy after birth in prenatally diagnosed congenital pulmonary airway malformation. J Pediatr Surg. 2018 Dec;53(12): 2386-9.

42 Girsen AI, Hintz SR, Sammour R, Naqvi A, El-Sayed YY, Sherwin K, et al. Prediction of neonatal respiratory distress in pregnancies complicated by fetal lung masses. Prenat Diagn. 2017 Mar;37(3):266-72.

43 Greig CJ, Keiser AM, Cleary MA, Stitelman $\mathrm{DH}$, Christison-Lagay ER, Ozgediz DE, et al. Routine postnatal chest $\mathrm{x}$-ray and intensive care admission are unnecessary for a majority of infants with congenital lung malformations. J Pediatr Surg. 2019 Apr;54(4):670-74.

44 Hellmund A, Berg C, Geipel A, Bludau M, Heydweiller A, Bachour H, et al. Prenatal Diagnosis and Evaluation of Sonographic Predictors for Intervention and Adverse Outcome in Congenital Pulmonary Airway Malformation. PLoS One. 2016 Mar;11(3): e0150474.

45 Japanese Study Group of Pediatric Chest Surgery, Kuroda T, Nishijima E, Maeda K, Fuchimoto Y, Hirobe S, Tazuke Y, et al. Perinatal features of congenital cystic lung diseases: results of a nationwide multicentric study in Japan. Pediatr Surg Int. 2016 Sep; 32(9):827-31.
46 Kane SC, Da Silva Costa F, Crameri JA, Reidy KL, Kaganov H, Palma-Dias R: Antenatal assessment and postnatal outcome of fetal echogenic lung lesions: a decade's experience at a tertiary referral hospital. J Matern Fetal Neonatal Med. Epub 2017 Oct 16:1-7.

47 Kunisaki SM, Barnewolt CE, Estroff JA, Ward VL, Nemes LP, Fauza DO, et al. Large fetal congenital cystic adenomatoid malformations: growth trends and patient survival. J Pediatr Surg. 2007 Feb;42(2):404-10.

48 Kunisaki SM, Ehrenberg-Buchner S, Dillman JR, Smith EA, Mychaliska GB, Treadwell MC. Vanishing fetal lung malformations: prenatal sonographic characteristics and postnatal outcomes. J Pediatr Surg. 2015 Jun;50(6): 978-82.

49 Kuroda T, Morikawa N, Kitano Y, Sago H, Hayashi S, Honna T, et al. Clinicopathologic assessment of prenatally diagnosed lung diseases. J Pediatr Surg. 2006 Dec;41(12):202831.

50 Lin MF, Xie HN, Zhao XH, Peng R, Zheng J, Peng ZP. Systemic Venous Drainage Is Associated with an Unfavorable Prenatal Behavior in Fetal Bronchopulmonary Sequestration. Fetal Diagn Ther. 2018;44(4):291-8.

51 Litwińska M, Litwińska E, Janiak K, Piaseczna-Piotrowska A, Gulczyńska E, Szaflik K. Thoracoamniotic Shunts in Macrocystic Lung Lesions: Case Series and Review of the Literature. Fetal Diagn Ther. 2017;41(3):17983.

52 Loh KC, Jelin E, Hirose S, Feldstein V, Goldstein R, Lee H. Microcystic congenital pulmonary airway malformation with hydrops fetalis: steroids vs open fetal resection. J Pediatr Surg. 2012 Jan;47(1):36-9.

53 Makhijani AV, Wong FY. Conservative postnatal management of antenatally diagnosed congenital pulmonary airway malformations. J Paediatr Child Health. 2018 Mar;54(3):26771.

54 Menon P, Binu V, Narasimha Rao KL, Suri V. Trends in Referral Pattern of Antenatally Diagnosed Surgical Abnormalities in a Tertiary Care Center in North India. J Indian Assoc Pediatr Surg. 2018 Oct-Dec;23(4): 198-202.

55 Mon RA, Johnson KN, Ladino-Torres M, Heider A, Mychaliska GB, Treadwell MC, et al. Diagnostic accuracy of imaging studies in congenital lung malformations. Arch Dis Child Fetal Neonatal Ed. 2019 Jul;104(4); F372-77.

56 Morris LM, Lim FY, Livingston JC, Polzin WJ, Crombleholme TM. High-risk fetal congenital pulmonary airway malformations have a variable response to steroids. J Pediatr Surg. 2009 Jan;44(1):60-5.

57 Oliver ER, DeBari SE, Giannone MM, Pogoriler JE, Johnson AM, Horii SC, Gebb JS, Howell LJ, Adzick NS, Coleman BG: Going With the Flow: An Aid in Detecting and Differentiating Bronchopulmonary Sequestrations and Hybrid Lesions. J Ultrasound Med. 2018;37:371-83.
58 Oliver ER, DeBari SE, Horii SC, Pogoriler JE, Victoria T, Khalek N, Howell LJ, Adzick NS, Coleman BG: Congenital Lobar Overinflation: A Rare Enigmatic Lung Lesion on Prenatal Ultrasound and Magnetic Resonance Imaging. J Ultrasound Med. Epub 2018 Sep 12.

59 Peranteau WH, Adzick NS, Boelig MM, Flake AW, Hedrick HL, Howell LJ, et al. Thoracoamniotic shunts for the management of fetal lung lesions and pleural effusions: a singleinstitution review and predictors of survival in 75 cases. J Pediatr Surg. 2015 Feb;50(2): 301-5.

60 Peranteau WH, Boelig MM, Khalek N, Moldenhauer JS, Martinez-Poyer J, Hedrick HL, et al. Effect of single and multiple courses of maternal betamethasone on prenatal congenital lung lesion growth and fetal survival. $J \mathrm{Pe}$ diatr Surg. 2016 Jan;51(1):28-32.

61 Peranteau WH, Merchant AM, Hedrick HL, Liechty KW, Howell LJ, Flake AW, et al. Prenatal course and postnatal management of peripheral bronchial atresia: association with congenital cystic adenomatoid malformation of the lung. Fetal Diagn Ther. 2008;24(3): 190-6.

62 Peranteau WH, Wilson RD, Liechty KW, Johnson MP, Bebbington MW, Hedrick HL, et al. Effect of maternal betamethasone administration on prenatal congenital cystic adenomatoid malformation growth and fetal survival. Fetal Diagn Ther. 2007;22(5):36571.

63 Riley JS, Urwin JW, Oliver ER, Coleman BG, Khalek N, Moldenhauer JS, et al. Prenatal growth characteristics and pre/postnatal management of bronchopulmonary sequestrations. J Pediatr Surg. 2018 Feb;53(2): 265-9.

64 Ruchonnet-Metrailler I, Leroy-Terquem E, Stirnemann J, Cros P, Ducoin H, Hadchouel A, et al. Neonatal outcomes of prenatally diagnosed congenital pulmonary malformations. Pediatrics. 2014 May;133(5):e128591.

65 Schrey S, Kelly EN, Langer JC, Davies GA, Windrim R, Seaward PG, Ryan G: Fetal thoracoamniotic shunting for large macrocystic congenital cystic adenomatoid malformations of the lung. Ultrasound Obstet Gynecol 2012 May;39(5):515-20.

66 Shulman R, Sparks TN, Gosnell K, Blat C Norton ME, Lee H, et al. Fetal Congenital Pulmonary Airway Malformation: The Role of an Objective Measurement of Cardiomediastinal Shift. Am J Perinatol. Epub 2018 Sep 10.

67 Stoiber B, Moehrlen U, Kurmanavicius J, Meuli M, Haslinger C, Zimmermann R, et al. Congenital Lung Lesion: Prenatal Course, Therapy and Predictors of Perinatal Outcome. Ultraschall Med. 2017 Apr;38(2):15865.

68 Style CC, Cass DL, Verla MA, Cruz SM, Lau $\mathrm{PE}$, Lee TC, et al. Early vs late resection of asymptomatic congenital lung malformations. J Pediatr Surg. 2019 Jan;54(1):70-4. 
69 Tuzovic L, Copel JA, Stitelman DH, Levit O, Bahtiyar MO: Utility of Fetal Cardiac Axis and Cardiac Position Assessment in Predicting Neonatal Respiratory Morbidity in Fetal Congenital Lung Lesions. J Ultrasound Med. Epub 2019 Jan 17. https://doi.org/10.1002/ jum.14931.

70 Vrecenak JD, Howell LJ, Khalek N, Moldenhauer JS, Johnson MP, Coleman BG, et al. Outcomes of prenatally diagnosed lung lesions in multigestational pregnancies. Fetal Diagn Ther. 2014;36(4):312-9.
71 Xia B, Yu G, Liu C, Hong C, Tang J. Surgical treatment of congenital cystic adenomatoid malformation: a retrospective study of single tertiary center experience. J Matern Fetal Neonatal Med. 2017 Feb;30(4):416-9.

72 Yong PJ, Von Dadelszen P, Carpara D, Lim K, Kent N, Tessier F, et al. Prediction of pediatric outcome after prenatal diagnosis and expectant antenatal management of congenital cystic adenomatoid malformation. Fetal Diagn Ther. 2012;31(2):94-102.

73 Zamora IJ, Sheikh F, Cassady CI, Olutoye OO, Mehollin-Ray AR, Ruano R, et al. Fetal MRI lung volumes are predictive of perinatal outcomes in fetuses with congenital lung masses. J Pediatr Surg. 2014 Jun;49(6):853-8; discussion 858 .
74 Mann CJ. Observational research methods. Research design II: cohort, cross sectional, and case-control studies. Emerg Med J. 2003 Jan;20(1):54-60.

75 Braakhekke M, Kamphuis EI, van Rumste MM, Mol F, van der Veen F, Mol BW. How are neonatal and maternal outcomes reported in randomised controlled trials (RCTs) in reproductive medicine? Hum Reprod. 2014 Jun;29(6):1211-7. 